\title{
JM KELly'S THE IRISH CONSTITUTION
}

\author{
by $G$ Hogan and $G$ Whyte, 3rd edition, Dublin, Butterworths, 1994, $1222+$ cxxii \\ pages (including index)
}

\section{Reviewed by Andrew Butler}

New Zealand public law has been undergoing something of a spurt of interest of late. Several books on New Zealand constitutional and administrative law have been published recently. Interest has been kindled doubtless by the enactment of the Official Information Act 1982, the Constitution Act 1986, the New Zealand Bill of Rights Act 1990, the MMP consultative referendum and subsequent legislation, the Privacy Act 1993 and other significant public law statutes. A noticeable feature of the commentary and jurisprudence on modern New Zealand public law has been the willingness to draw on comparative material. And among those jurisdictions consistently referred to is the system of the single transferable vote (a form of proportional representation) prescribed by Art $16.2 .5^{\circ}$ of the Irish Constitution. ${ }^{1}$ Similarly, in a number of cases the courts have referred to Irish cases in determining the true scope of rights and freedoms guaranteed by the Bill of Rights. A series of Irish cases on constitutional torts was referred to by the Court of Appeal in the Baigent case, ${ }^{2}$ while the Irish approach to the exclusion of unconstitutionally obtained evidence (the vindication approach) appears to have been influential in the formulation and operation of our prima facie exclusion rule. ${ }^{3}$ Moreover, with the debate over republicanism gaining momentum, it is inevitable that proponents of a republic will be looking overseas for models of a presidency suitable to New Zealand. It may be that, as in Australia, the Irish model of a popularly elected president with certain limited reserve-style powers will provide useful. The question then facing the practitioner and academic interested in pursuing aspects of Irish law is choosing a text. As will become apparent, Kelly's Irish Constitution is to be commended.

Within a short time of its first appearance, Kelly had established itself as the leading text on the Irish Constitution. Authored by John Kelly, Member of Parliament, ex-Attorney-

\footnotetext{
* Lecturer, Faculty of Law, Victoria University of Wellington.

1 See the Report of the Royal Commission on the Electoral System: Towards a Better Democracy (Government Printer, Wellington, 1986).

2 Simpson v Attorney-General [Baigent's Case] [1994] 3 NZLR 667; (1994) 1 HRNZ 42.

3 See $R v$ Goodwin [1993] 2 NZLR 153; [1990-92] 2 NZBORR 214.
} 
General, and professor of law, the book was a remarkable synthesis of constitutional jurisprudence and practice with an insider's insights on the practical workings of state institutions. That commendable approach was maintined in the second edition, and since Kelly's untimely death in 1993, has been continued by Messrs Hogan and Whyte in the third. Throughout, the background to cases and issues is disclosed so that readers have a good appreciation of the concerns which surrounded a particular decision. The level of analysis is generally excellent: it is both interpretative and purposive, a positive boon for the overseas reader who can separate matters of text from matters of substance rather readily, thereby making comparison much more straightforward.

The book follows an article by article approach. In many cases the discussion of a particular article or sub-article is broken down under useful headings. The comprehensiveness of the coverage of the relevant case law is the greatest strength which the book offers.

Hardly a relevant case or relevant dictum goes unnoticed. An especially useful feature of the book's presentation from the perspective of the practitioner-reader (and particularly the overseas practitioner who may not have ready access to the various Irish law reports) is the reproduction in extenso of extracts from judgments. These enable the reader to assess for themselves the validity of the commentary made by the authors (and for the overseas reader assist in direct quotation of authority). ${ }^{4}$

Users of the two previous editions will, in all likelihood, have shared the writer's frustration in consulting Kelly which the inadequate indexing created. Fortunately, in the latest version some attention has been paid to this important feature of the book and the result is a much more user-friendly and comprehensive index.

The current authors have expanded the extent of reference to overseas authorities. Apart from US authorities, a large slice of the case law emanating from the European Convention on Human Rights organs is referred to. Unfortunately, this development has not seen a great expansion in reference to Commonwealth authorities. Despite the large numbers of Canadian Charter decisions which relevantly touch upon many of the issues discussed in the text, few are cited by the authors. ${ }^{5}$ Similarly, references to Indian and other

4 The only difficulty in relation to the latter is that for some reason the authors do not supply the page references for any of the quotations provided in the book.

5 One example alone relates to the discussion of restrictions on the right to vote and on the ability of state officials to participate in political activity on which there are many interesting Canadian cases: see eg Sauvé vanada (Attorney General) and Belczowski v R [1993] 2 SCR 438 (with references to the lower appeal court rulings) (prisoners' right to vote), Re Hoogbruin and Attorney-General of British Columbia (1985) 24 DLR (4th) 718 (right to absentee ballot), Osborne $v$ Canada (Treasury Board) [1991] 2 SCR 69 (prohibition on public servants engaging in political work too broad). 
Commonwealth jurisdictions are few. In addition, while there are references to a number of German cases one hopes that in any future editions the extent of such comparative work will be expanded in light of the fact that, despite language barriers, there is a growing amount of writing on the Grundgesetz in English and efforts by the Constitutional Court itself to make its judgments more accessible.

One disappointing feature of the book must however be mentioned. The publisher is Butterworths and one would have expected a higher standard of editing and proofing. There are simply too many typographical errors in the book, from repetitions, ${ }^{6}$ to misspellings, to footnoting which does not correspond. ${ }^{7}$ Hopefully, the next edition will be able to tackle difficulties in this area.

In conclusion, Kelly is a worthwhile purchase for anyone for whom it is necessary to have ready, comprehensible and comprehensive access to Irish constitutional law.

$6 \quad$ See eg p 166.

7 See the chapter entitled "The Family and Education" p 989ff. 